\title{
Is global dietary change an effective strategy to curb climate change?
}

\author{
James Bradfield (D) , ${ }^{1,2}$ Helena Trigueiro, ${ }^{2}$ Sumantra Ray (D) 2,3,4
}

Since the dawn of agriculture, humankind has constantly strived to improve food availability and food systems. The agricultural revolution which began in the mid-17th century and continued well into the 19th century accelerated this improvement and contributed to a growth in population and improvement in health. Since then the population has continued to rise and with it, the consequent environmental complications.

Global population is now estimated at 7.7 billion people ${ }^{1}$ with a potential growth to almost 11 billion by $2100,{ }^{1}$ underlining the challenge to feed everyone. Research has shown that we are currently not doing this822 million people are undernourished, a fact linked with almost half of child mortality globally. ${ }^{2}$ However, the solution to this problem cannot simply be to produce more food, particularly when the Food and Agriculture Organization of the United Nations estimates that one-third of all food produced for human consumption is lost or wasted. ${ }^{3}$ The need for change is reflected in the United Nations' Sustainable Development Goal 2.4 which aims to improve the sustainability of food production, increasing productivity while maintaining ecosystems, by 2030.

While food systems must be examined, it is also worth noting the differing impacts of the types of foods that we produce. Of Earth's total ice-free land surface, approximately $40 \%$ is used as cropland and pasture, and the

\footnotetext{
${ }^{1}$ Clinical Sciences and Nutrition, University of Chester, Chester, UK

${ }^{2}$ NNEPro Global Centre for Nutrition and Health in Cambridge, Cambridge, UK

${ }^{3}$ School of Biomedical Sciences, Ulster University, Coleraine, UK

${ }^{4}$ School of Humanities and Social Sciences, University of Cambridge, Cambridge, UK
}

Correspondence to Professor Sumantra Ray, NNEdPro Global Centre for Nutrition and Health, St John's Innovation Centre, Cambridge CB4 OWS, UK; s.ray@nnedpro.org.uk conversion of traditional ecosystems to farmland is the largest factor threatening species' extinction. ${ }^{4}$ Nevertheless, 'food' is a non-specific term and one which can refer to many different types of products. Producing $1 \mathrm{~kg}$ of lamb or mutton requires $369.81 \mathrm{~m}^{2}$ of land compared with $12.22 \mathrm{~m}^{2}$ for $1 \mathrm{~kg}$ of poultry meat and $2.97 \mathrm{~m}^{2}$ for $1 \mathrm{~kg}$ of farmed prawns. ${ }^{5}$ Examining greenhouse-gas emissions associated with production of $1 \mathrm{~kg}$ of beef, poultry and root vegetables, it tells a similar story with 60, 6 and $0.4 \mathrm{~kg} \mathrm{CO} /$ $\mathrm{kg}$, respectively. ${ }^{5}$ Irrigating cropland is the largest human use of freshwater, accounting for $66 \%$ of annual resources, while food production is responsible for approximately $30 \%$ of the global greenhouse-gas emissions. ${ }^{67}$

There has been significant coverage in the last number of years in strategies to adopt a plant based diet. The EAT-Lancet Commission ${ }^{8}$ called for a complete transformation of the global food system, endorsing a diet made up primarily of fruit and vegetables, whole grains, legumes, nuts and unsaturated oils combined with low/moderate seafood and poultry and low/no red or processed meat, added sugar, refined grains or starchy vegetables.

It has been estimated that increased consumption of plant-based diets might lower greenhouse-gas emissions by up to $80 \%$. $^{9}$ Unfortunately, simply advising dietary change is not likely to be productive advice. Affordability analysis of the dietary patterns advised in the EATLancet show that it may be unattainable for over 1.58 billion people around the world, ${ }^{10}$ particularly from low-income countries where $89.1 \%$ of the mean per capita household income would be spent on food to meet these targets. ${ }^{1011}$

Ongoing climate change must also be considered a major factor in food security. Changes in weather patterns are the significant threat to crop production in Europe with experts warning that urgent action is needed to add resilience to the agriculture $^{12} 13$ sector. Evidence shows that these negative effects will be more pronounced for individuals living in low-income and middle-income countries, contributing to the aggravation of current social inequities. ${ }^{10}$ The recent onset of the COVID-19 pandemic may provide some insight into what interruptions to the food supply chain may look like should climate change continue to advance in such a manner. The current pandemic also highlights the importance of adequate nutritional status ${ }^{14}$ and creating localised (low-carbon) food supply chains which are more resilient, as such supply chains have been significantly disrupted due to the COVID-19 crisis resulting in acute food insecurity.

If greenhouse-gas emissions continue along their current trajectory, vegetable and legume production could decrease by $35 \%$ by 2100 due to water shortage and amplified salinity. ${ }^{15}$ In the same time period, corn production may be cut by half by a $4 \circ \mathrm{C}$ increase in global temperatures, while a temperature increase of under 2ㅇ C (in line with the Paris Climate Accord) could possibly reduce American corn production by approximately $18 \% .^{16}$

From a dietary point of view, there are three universal challenges: obesity, undernutrition and climate change. Climate change can be considered a serious threat to public health due to its direct effects on human health and the natural systems we depend on. Obesity, undernutrition and climate change can co-occur, interact and share common underlying social determinants. This represents a syndemic that affects almost everyone globally. ${ }^{17}$

Clearly, solving the current issues surrounding diet sustainability and climate change demands a multifactorial and multidisciplinary approach, requiring stakeholders from different backgrounds, political figures as well as individuals to implement changes needed to directly influence action. We must act now to reduce greenhouse-gas emissions throughout food systems and implement effective climate adaptations. ${ }^{18}$ On an individual level, promotion of predominantly plant-based diets in line with evidence on healthy eating (not 
necessarily vegan or vegetarian) is a fitting approach for sustainable diets, bearing in mind the cost implications, biodiversity, nutritional adequacy, fair-trade and cultural preferences. From a food systems point of view, the agricultural sector, governments and consumers must must seriously consider the need to modernise and streamline practices in order to ensure that climate targets are reached in time.

Contributors This article was jointly written by JB and $\mathrm{HT}$ with review, comments and supervision from SR.

Funding All three authors are supported by the NNEdPro Global Centre for Nutrition and Health.

Competing interests There are no competing interests.

Patient consent for publication Not required.

Provenance and peer review Commissioned; internally peer reviewed.

\section{() OPEN ACCESS}

Open Access This is an open access article distributed in accordance with the Creative Commons Attribution Non Commercial (CC BY-NC 4.0) license, which permits others to distribute, remix, adapt, build upon this work non-commercially, and license their derivative works on different terms, provided the original work is properly cited, appropriate credit is given, any changes made indicated, and the use is non-commercial. See: http://creativecommons.org/ licenses/by-nc/4.0/.
C Author(s) (or their employer(s)) 2020. Re-use permitted under CC BY-NC. No commercial re-use. See rights and permissions. Published by BMJ.

A) Check for updates

To cite Bradfield J, Trigueiro H, Ray S. Is global dietary change an effective strategy to curb climate change? BMJ Nutrition, Prevention \& Health 2020;3:e000101. doi:10.1136/bmjnph-2020-000101

Received 10 May 2020

Revised 1 June 2020

Accepted 4 June 2020

Published Online First 2 July 2020

bmjnph 2020;3:e000101.

doi:10.1136/bmjnph-2020-000101

ORCID iDs

James Bradfield http://orcid.org/

0000-0002-1010-2372

Sumantra Ray http://orcid.org/0000-0003-3295-168X

\section{REFERENCES}

1 United Nations, Department of Economic and Social Affairs, Population Division.

World population prospects 2019 : highlights (ST/ESA/SER.A/423) 2019.

2 FAO I, UNICEF, WFP, WHO. The state of food security in the world 2019.

3 FAO, Food Wastage Footprint, United Nations. Food wastage footprint: impacts on natural resources, summary report 2013.

4 Foley JA, Ramankutty N, Brauman KA, et al. Solutions for a cultivated planet. Nature 2011;478:337-42.

5 Poore J, Nemecek T. Reducing food's environmental impacts through producers and consumers. Science 2018;360:987-92.

6 Brauman KA, Richter BD, Postel S. Water depletion:an improved metric for incorporating seasonal and dry-year water scarcity into water risk assessments. Elementa: $\mathrm{Sci}$ Anthropocene 2016.
7 Vermeulen SJ, Campbell BM, Ingram JSI. Climate change and food systems. Annu Rev Environ Resour 2012;37:195-222.

8 EAT. The EAT-Lancet Commission on Food, Planet, Health - EAT, 2019. Available: https://eatforum.org/eatlancet-commission/ [Accessed 24 Mar 2020].

9 Springmann M, Clark M, Mason-D'Croz $\mathrm{D}$, et al. Options for keeping the food system within environmental limits. Nature 2018:562:519-25.

10 Hirvonen K, Bai Y, Headey D, et al. Affordability of the EAT-Lancet reference diet: a global analysis. Lancet Glob Health 2020;8:e59-66.

11 Nguyen TT, Trevisan M. Vietnam a country in transition: health challenges. BMJNPH 2020;3:60-6.

12 European Academies Science Advisory Council. German national Academy of sciences Leopoldina. trends in extreme weather events in Europe: implications for national and European Union adaptation strategies 2013.

13 Watts N, Adger WN, Agnolucci P, et al. Health and climate change: policy responses to protect public health. Lancet 2015;386:1861-914.

14 Lanham-New SA, Webb AR, Cashman $\mathrm{KD}$, et al. Vitamin D and SARS-CoV-2 virus/COVID-19 disease. BMJNPH 2020;3:106-10.

15 Scheelbeek PFD, Bird FA, Tuomisto HL, et al. Effect of environmental changes on vegetable and legume yields and nutritional quality. Proc Natl Acad Sci U S A 2018;115:6804-9.

16 Tigchelaar M, Battisti DS, Naylor RL, et al. Future warming increases probability of globally synchronized maize production shocks. Proc Natl Acad Sci U S A 2018:115:6644-9.

17 Swinburn BA, Kraak VI, Allender S, et al. The global Syndemic of obesity, undernutrition, and climate change: the Lancet Commission report. Lancet 2019;393:791-846.

18 Campbell BM, Vermeulen SJ, Aggarwal $\mathrm{PK}$, et al. Reducing risks to food security from climate change. Glob Food Sec 2016;11:34-43. 